\title{
Marilyn, los intelectuales y la industria
}

\begin{abstract}
RESUMO
O artigo tem como objetivo responder a pergunta que se fazem Martín Barbero e Germán Rey: Por que os intelectuais latino-americanos têm um olhar negativo ao abordar os problemas culturais e em especial os relativos à televisão?Argumentar-se-á que o chamado "olhar negativo" se configura a partir de um preconceito a respeito do que é um intelectual, de um imaginário social que se originou no devir da cultura ocidental. Tal assunto pode-se registrar a partir da hegemonia do mundo cristão no ocidente que se intensifica com o surgimento da modernidade. Tal situação, "o olhar negativo", se caracteriza pela separação entre o pensar e a vida cotidiana. Finalmente, evidencia-se uma visão sobre uma telenovela colombiana tal qual acontece no âmbito da televisão.
\end{abstract}

\section{PALAVRAS-CHAVE}

- intelectuais latino-americanos

- modernidade

- telenovela colombiana

\section{RESUMEN}

El artículo tiene por objeto hacerse cargo de la pregunta que se hacen Martín Barbero y Germán Rey, ¿Por qué los intelectuales latinoamericanos tienen un mal ojo para abordar los problemas culturales y en especial los relativos a la televisión? Se argumentará que el llamado "mal ojo" se configura a partir de un prejuicio de lo que es un intelectual, de un imaginario social que se gestó en el devenir de la cultura occidental. Tal asunto se puede registrar a partir de la hegemonía del mundo cristiano en occidente que se maximiza con el surgimiento de la modernidad. Tal enfermedad, "el mal ojo", se caracteriza por el divorcio entre el pensar y la vida cotidiana. Finalmente, se despliega la mirada sobre una telenovela colombiana como muestra de lo que acontece en el ámbito de la televisión.

\section{PALABRAS-CLAVE}

- intelectuales latinoamericanos

- modernidad

- telenovela colombiana

\section{Jonatan Alzuru Aponte UCV}

El título de nuestro trabajo revela desde cuál tradición pensamos, al colocar el concepto industria cultural dentro del mismo, sin necesidad de explicitar la relación entre los términos que lo conforman. Evidentemente, nos inscribimos, de alguna manera, en la tradición heterodoxa del marxismo inaugurada por la Escuela de Frankfurt.

Obviamente, el lenguaje no es gratuito, implica riesgos, porque da cuenta desde dónde se piensa, cuál es la biblioteca que se utiliza para plantear, caracterizar e interpelar los asuntos que se consideran relevantes.

La ventaja de explicitar tal uso, colocar en la mesa los libros desde el cuál pensamos algunos problemas, es la conformación de una plataforma común, un terreno de juego compartido, un ámbito de comprensión que posibilita una interacción fluida con el interlocutor. Los peligros de tal acción están configurados por los prejuicios, los juicios previos, que se tienen sobre un pensamiento, una mirada, una corriente política, sociológica y/o filosófica que imposibilitan la afabilidad necesaria con aquello que se comparte, el permanente dique que existe en la tensión dialógica.

La claridad de los beneficios y costos del lenguaje es una condición necesaria que conduce a que se explicite, con mayor delicadeza, la mirada de uno sobre el asunto, sobre las interrogaciones, los conceptos, las metáforas y hasta los silencios que lo configuran, con la conciencia permanente que la opacidad del lenguaje es constitutivo del mismo. Pero con la persistencia hermenéutica de acercarnos y diferenciarnos de la trama discursiva que nos constituye con la finalidad de hacer traslúcida nuestra mirada.

La riqueza está en el disfrute lúdico de la tensión entre opacidad y transparencia de la herramienta lingüística que posibilita delinear el boceto del problema pensado, y en la sensibilidad para demandar lo planteado con la porosidad necesaria de aquél que se deja impregnar por el lenguaje del otro. Lo que hemos caracterizado no es otra cosa que la condición necesaria de todo diálogo: la sensibilidad hermenéutica del pensar.

\section{¿Cuál es el Problema?}

Nuestro parlamento lo iniciamos planteando nuestro título como una relación entre un nombre femenino Marilyn que evoca un icono del cine de los años sesenta y que le dio nombre a una telenovela colombiana en 2004, el rol de unos actores sociales, los intelectuales y un concepto acuñado por Adorno y Horkheimer. El título es una manera de nombrar el problema que nos ocupa. Nos hicimos cargo de la pregunta que Martín-Barbero y Germán Rey (1999), en su libro Los ejercicios del ver, se hicieron, a saber:

Por qué los intelectuales y las ciencias sociales 
en América Latina siguen mayoritariamente padeciendo de un pertinaz [mal de ojo] que les hace insensibles a los retos culturales que plantean los medios, insensibilidad que se intensifica hacia la televisión. (Barbero y Rey: 17)

La tesis que sostendremos es que la televisión, como uno de los productos de la industria cultural, se configuró en un actor más de la vida cotidiana, como la familia o los amigos, de allí su fuerza y potencia en la construcción de imaginarios sociales, transformándose, como diría Marcuse, en un elemento más de la amalgama de la cultura material. Acontecimiento inscrito dentro de un ambiente global de massmediatización tanto de las configuraciones como de las dinámicas sociales, siendo tal fenómeno la característica de una nueva condición epocal. Tal afirmación implica que la mirada, la discusión, a propósito de la industria cultural se hace compleja, requiere de un pensar complejo atento a los cotidiano, porque sus lógicas se desterritorializaron y su metamorfosis se dio al interior de las instituciones sociales y políticas, configurando un nuevo equipamiento de la subjetividad.

"El mal ojo de los intelectuales" para abordar tal fenómeno es consecuencia de un síndrome que se configuró en el devenir de la cultura de occidente. Apenas, en este texto, haremos el boceto de algunos de sus síntomas: la interpretación que realizan algunos intelectuales sobre la industria cultural.

Se mostrará que la mirada intelectual sobre la televisión está anclada en un estereotipo social e histórico que se configura como un imaginario de quién es el intelectual, tal percepción de sí y del entorno social tiene como sedimento, la noción romana de cultura.

Otra arista del síntoma es la impronta de la cultura escolástica, la cultura medieval, como huella que articula y dinamiza a las instituciones donde se forman los intelectuales, las universidades. Tal herencia es la práctica de asumir la interpretación de autores, la hermenéutica del texto, como el único horizonte, en tanto deber ser, del quehacer intelectual. Tal ejercicio implicó la atrofia tanto de la mirada como de la sensibilidad para abordar la vida cotidiana. Ergo, si la televisión forma parte de lo cotidiano, entonces, el intelectual no tiene entrenamiento para ver lo que en ella sucede (aunque viva, paradójicamente, en una cultura mediática) pero además, no le interesa saber lo que en ella sucede, en primer lugar por la percepción que tiene de sí y en segundo lugar, por el concepto que tiene de la industria.

Coincidimos con Barbero y Rey que narrar tal vacío dejado por la mirada del intelectual es indispensable no sólo para desenmascarar las relaciones de dominación, mostrar sus articulaciones hegemónicas, sino para hacer relevante los acontecimientos de ruptura y continuidad que potencian, promueven y desarrollan la construcción de imaginarios e identidades sociales, como fragmentos emancipatorios, esquirlas que distorsionan, conmueven y revolucionan las narrati- vas del deber ser, como la teología, la política, la moral... La Ciencia.

Pues nos encante o nos dé asco, la televisión constituye hoy al vez el más sofisticado dispositivo de moldeamiento y deformación de la cotidianidad y los gustos de los sectores populares, y una de las mediaciones históricas más expresivas de matrices narrativas, gestuales y escenográficas del mundo cultural popular, entendiendo por éste no las tradiciones específicas e un pueblo sino la hibridación de ciertas formas de enunciación, ciertos saberes narrativos, ciertos géneros novelescos y dramáticos de las culturas de occidente y de las mestizas culturas de nuestros países.(Barbero y Rey, 1999: 18)

\section{¿Usted dijo telenovela? \\ Disculpe yo no veo eso, soy intelectual}

En este parágrafo ilustraremos dos miradas antagónicas, pero relevantes en los protocolos del debate contemporáneo, sobre las telenovelas en particular y la industria cultural en general, con la finalidad de mostrar los presupuestos comunes que comparten, los imaginarios que las sostienen. Luego se graficará algunos rasgos del clima de estos tiempos, con el propósito de mostrar la importancia de mirar de otra manera los problemas mediáticos encofrados en una civilización donde ellos se han convertidos en centralidad.

Una tendencia intelectual sostiene que la telenovela es un producto de la industria cultural, es el melodrama en serie, repetido, reiterado y calibrado por el mercado, es una mercancía delimitada y estructurada por la oferta y la demanda, cuyo sentido es distraer a las grandes mayorías del mundo real, su sentido es configurar momentos para olvidarse de la densidad de la vida.

La Telenovela triunfa cuando el receptor se olvida de sí y se entrega sin ninguna resistencia a la ficción. Ella está articulada con imágenes y discursos estereotipados, donde la niña pobre, pero de corazón impoluto, sufre las consecuencias de amar desinteresada e inocentemente al joven de familia burguesa, quien hace lo imposible para amarla, pero el entorno, los familiares, amigos y novias pasadas, se encargan de prohibir y obstaculizar de las formas más inhumanamente posibles tal relación. Y, quizás, por un golpe de azar o por fuerza del destino, todos los roles se cambian y la pobre se hace rica y el joven rico padece las tormentas de la prisión y la injuria, para finalmente reencontrar el amor en aquella campesinita, marginal y sirvienta que en ciento veinte episodios no sólo cambió la forma y manera de hablar y vestirse, sino que aprovecha los avances de la medicina estética para vivenciar la metamorfosis de su cuerpo, adelga$\mathrm{za}$, se hace rubia, delinea sus labios y sus dientes resplandecientes se hacen la esperanza de los desdentados del planeta. El amor vence a la maldad.

Tal narrativa es consustancial con la industria que la produce. La industria, los grandes medios de co- 
municación, se han transformado en uno de los engranajes fundamentales de la gran maquinaria capitalista donde el hombre se hace mercancía en la misma medida que la produce, tal como sostenía Marx en sus escritos de juventud. Precisamente, lo afín con el hombre-cosa es la deglución del melodrama como una expresión más de la enajenación en la que vive. Por lo tanto, un hombre con conciencia es aquél quien lucha contra la explotación, contra los dueños de los medios de producción, y, por tanto, no tienen tiempo que perder en su tarea, por ello es incapaz de distraerse viendo televisión, porque ella idiotiza y, en el colmo de su flexibilidad, la ve de forma crítica. Pero jamás vería un melodrama completo, quiénes lo hacen son los enajenados, dígase, el proletariado, los pobres.

El otro grueso de la población intelectual caracteriza el melodrama de la misma forma, un bodrio repetido, pero para ellos es válido y hasta necesario, porque el consumidor es libre de escoger la mercancía que desea consumir. Si se vende es porque alguien la consume. El televidente tiene el poder de cambiar el canal. En cada canal se vende un tipo de programación. Ellos, los canales con sus programaciones, compiten entre sí y tendrá mayor sintonía quien venda la mejor programación. Esa es una de las formas de manifestarse la libertad que se ha conseguido en el transcurrir del tiempo en occidente. Eso ha dado resultado, es el único camino del progreso.

El problema no está en la industria de la televisión sino en la educación de la sociedad. Una persona culta consumirá una programación que abone su florecimiento espiritual, porque su mirada no soportará algo distinto, las sutilezas y elegancias para distraerse las podría buscar y encontrar en algún dramedy de $\mathrm{HBO}$, porque en la programación por cable hay opciones para todos.

Sin embargo, y al parecer es obvio, que los pertenecientes al estatus de las personas cultas son aquellas quienes consumen lo mínimo de la programación televisiva. Su recreación está en el buen cine, en el buen teatro y en la lectura de poesías, cuentos y novelas. El melodrama está reservado para la señora de servicio, el chofer, el taxista... esa pobre gente marginal.

El punto común, entre las miradas antagónicas que hemos caracterizado, es en la acción: ver lo mínimo la televisión y nunca melodramas. También en la ubicación del sector social que consume melodrama: los pobres y/o los que tienen un bajo nivel educativo. Tal punto común es una impronta estereotipada que se reproduce en nuestra sociedad. Martín-Barbero y Germán Rey lo describen mostrando un dato cualitativo:

“ ¡Hasta los maestros de escuela niegan que ven televisión, creyendo así defender ante los alumnos su hoy menguada autoridad intelectual!" (Barbero y Rey, 1999: 17)
Valga la reiteración, para explicitar aún más el argumento, las miradas políticamente opuestas, que hemos caracterizado a propósito de la industria cultural, coinciden que:

Es innegable - para decirlo con las palabras de Leoncio Barrios - que ciertos sectores de cualquier población, precisamente los más depauperados educativamente, disfruten con la chabacanería y morbosidad que promueven ciertos medios de comunicación, pero también es cierto que a esos mismos sectores la sociedad les ha negado la posibilidad de aprender el disfrute de mensajes más elaborados y de gusto más refinado, estableciendo un ciclo de manipulación colectiva. (Barrios, 1999:39)

El supuesto implícito, de tales miradas, está anclado en una concepción tradicional de la cultura, cultura animi en el lenguaje de Cicerón, el esfuerzo por sembrar y cultivar el espíritu, en formarse; para decirlo con la distinción de cultura realizada por Herbert Marcuse (1971), aquella de los valores superiores, la ciencia, la literatura, el arte y la religión de la sociedad, dígase, la cultura intelectual. La masa no tiene cultura intelectual. La cultura de la masa está limitada a los patrones que se configuran en la vida cotidiana a través de la familia, los amigos, la educación, el trabajo, la cultura material.

La mirada estereotipada del intelectual a propósito de la televisión podría resumirse de la siguiente forma: Los que viven limitados a la cultura material son quienes consumen en mayor proporción los productos de la televisión y, sobre todo, las mercancías de peor calidad, entre ellas, los melodramas; quien tiene cultura intelectual consume productos de excelente calidad en la televisión, por ello, ve muy poca televisión.

Pareciera una curiosidad, por decir lo menos, que el estereotipo del intelectual, aquel quien tiene una cultura intelectual, se mantenga como imaginario y horizonte de sentido, del deber ser del ciudadano, en una sociedad massmediatizada. El vocablo, massmediático, utilizado como adjetivo de sociedad no alude ni a un grupo social, ni a un sector, ni a los desarrollos socio económicos ni industriales, tampoco se corresponde con un espacio delimitado geográficamente, sino a una época, a una condición del tiempo contemporáneo; su sentido intenta atrapar tanto su clima como las lógicas que se instalan y los dispositivos que se producen en el mundo actual, esto es, en la forma y manera de relacionarse los sujetos entre sí y éstos con las instituciones, como en la subjetividad que dispara, los dispositivos que produce. Tal característica ha determinado, según autores como Gianni Vattimo, el fin de la sociedad moderna que se configuró en el devenir del mundo viejo europeo.

Yo sostengo - afirma Vattimo - que el término 
posmoderno sigue teniendo un sentido, y que este sentido está ligado al hecho de que la sociedad en que vivimos es una sociedad de la comunicación generalizada, la sociedad de los medios de comunicación (mass media) (Vattimo, 1994:9)

Para el pensador italiano la irrupción de los medios de comunicación, de las nuevas tecnologías de la información que posibilitan comunicaciones globales, donde se presentan y se cruzan múltiples, variadas, diversas, encontradas, engrandadas y/o enfrentadas visiones del mundo configuradas desde las historias locales, han sido una "de las causas determinantes de la disolución de los puntos de vista centrales de lo que un filósofo francés, Jean François Lyotard, llama los grandes relatos"; a pesar del esfuerzo de las grandes trasnacionales por monopolizar los sentidos de la información, con el objeto de simular realidades al crearlas e interpretarlas manipulando sus imágenes.

Justamente, por la fuerza en la constitución de imaginarios colectivos de las industrias culturales en la sociedad massmediática, la lucha por el por el control de la información, se ha transformado en estos tiempo en la clave para permanecer y acrecentar el poder trasnacional, siendo tal fenómeno, paradójicamente, una tendencia sustancial del devenir de la cultura capitalista que se configuró en la sociedad medieval europea.

Utilizamos el término paradójico como una llamada de atención, necesaria, quizás para recordar el carácter dialéctico de la vida. Esto significa que los fenómenos sociales están articulados por las tensiones, dialécticas, entre preservación y cambio. En otras palabras, en lo que acontece, en la contingencia se encuentran ocultas las huellas del pasado, fragmentos arqueológicos, sedimentos, que han constituido horizontes de sentidos para antiguas comunidades y, quizás, persisten como tendencia dentro de una nueva perspectiva del quehacer.

Es por ello que el fenómeno de la lucha por el poder de la información en la sociedad massmediática es una característica de estos tiempos, pero su lógica está cargada de las huellas, de los sedimentos, de la misma pulsión del saber como poder, del saber como dominio de la naturaleza y el hombre, que fungió como horizonte en los albores de la modernidad.

En el marco de tales tensiones, entre preservación y cambio, la "... radio, televisión, prensa han venido a ser elementos de una explosión y multiplicación de Weltanschauungen, de concepciones del mundo." Tal irrupción de lo local en lo global hace estallar el sentido unitario de la historia al multiplicar sus imágenes. Se diluye la narración de un acontecimiento en múltiples miradas y perspectivas. No hay posibilidad de la supremacía de una interpretación sobre un acontecimiento y que éste se reproduzca en un solo sentido. En el mundo virtual y en la televisión se multiplican las interpretaciones y desatan en el mundo real, un destrabe de sentidos, de prácticas polimorfas. No hay posibilidad de legitimar la reconstrucción de la historia de un pueblo desde una sola mirada, la clase dominante puede contar su historia pero el dominado también. CNN narra, la guerra en Irak, desde la perspectiva de Estados Unidos y Al-Jazeera desde el mundo árabe. La condición en estos tiempos es la metamorfosis a miles de historias. El ojo ajustado del pensador de la sociedad se descentra. Las luchas microfísicas circunscritas a una región y a su historia se globalizan. El subcomandante Marcos es una voz en Chiapas que se manifiesta globalmente. El glocalismo es lo cotidiano.

Según Vattimo al multiplicarse las perspectivas, en acto, se pone en cuestión el concepto mismo de realidad. No hay un sustrato independiente de las perspectivas. El mundo real en la sociedad de la información es fábula.

La realidad, para nosotros, es más bien el cruzarse y "contaminarse" (en el sentido latino) de las múltiples imágenes, interpretaciones, re-construcciones que distribuyen los medios de comunicación en competencia mutua y, desde luego, sin coordinación central alguna. (Vattimo, 1994: 15)

Así como las imágenes del mundo se expanden y se multiplican, la lógica de la industria cultural engloba y unifica, en una relación directamente proporcional. La industria publicitaria se transforma en el norte de la real política, desplazando a los programas fundados en tácticas y estrategias, frutos de la interpretación de lo que acontece a la luz de un cuerpo teórico, doctrinario o ideológico que tenían los partidos políticos.

La metodología para realizar el estudio de mercado, en el lanzamiento de un producto comercial es la misma que se utiliza en las competencias electorales. El actor político, desde ésta perspectiva, se transforma en un producto cuya marca es su agrupación, movimiento o partido político, por lo tanto, la industria de la imagen que lo produce realiza estudios focales para establecer cómo y cuál es el discurso más adecuado, cómo y de qué forma vestirse, con quién y cómo debe presentarse, dónde y cuándo hacerlo, además de calibrar tales acciones con estudios estadísticos, porque el rating determina cuál es la fórmula ganadora para acceder y mantenerse en el poder.

La lógica de la publicidad como mirada de la participación política tiene el efecto contrario de la multiplicación de las imágenes del mundo, porque borra los linderos y las diferencias entre las tendencias políticas, las homogeniza, las unifica, un producto bien vendido puede ser de derecha, de centro, de izquierda, ecologista, actor de cine o actriz de películas porno, lo que prevalece es la imagen, ella está construida y elaborada, técnicamente, a partir de los estudios de mercados. La lógica de la publicidad ya no pertenece como exclusividad de las industrias cul- 
turales ${ }^{1}$, sino, y éste el argumento fuerte, a las instituciones políticas y sociales. Lo que afirmamos es que la lógica publicitaria se transformó en una manera de relacionarse, de interactuar, cohesionarse, de colocar en juego las fuerzas sociales y políticas. Se realizó, de alguna manera, el ideal industrial criticado por Adorno y Horkheimer: El ideal consiste en que la vida no pueda distinguirse más de los films.

Expresado de otra forma, la discusión política como ámbito y terreno de confrontación y/o negociación, la acción comunicativa en el escenario político, se debilita, al punto de hacerse prescindible, tanto en la competencia electoral, en el ejercicio de gobierno, en la sociedad civil, en los partidos políticos, dígase, en el ejercicio de la política, en la misma medida que se fortalece el marketing como horizonte de sentido del quehacer. El estudio de mercado, cuantitativa y cualitativamente, sustituye al análisis y a la argumentación política, el show reality (no a la inversa, no la realidad que se hace show en la televisión, reality show, sino el show que se hace realidad en la política) a las formas de luchas, entre otras variaciones.

Es por ello que el parlamento del actor político, en el teatro de lo público, no requiere coherencia con unos principios ideológicos, aunque los enuncie permanentemente, ni tampoco fidelidad a un plan de acción desde el cual se validen sus propuestas, su problema no son las buenas razones que fundamenten un conjunto de decisiones frente a las comunidades con el objeto de legitimarlas y validarlas; sino la imagen, el imperio de la imagen como estrategia de coacción, la empatía y la seducción (hay multiplicidad de formas de seducción, desde el beso y la flor hasta la cachetada y el látigo, desde Walt Disney hasta Tarantino...) como fórmulas para acrecentar o enfrentar el poder.

En el imperio de la imagen se manifiestan hegemonías que se corresponde con unos actores y con unas condiciones materiales. El vocablo hegemonía lo utilizo en el sentido de la tradición gramsciana, como la unidad (horizonte de acción e intereses comunes) existente en las formas sociales concretas. Cuando evocamos la noción de condiciones materiales es porque ellas tienen manifestaciones objetivas, sin lugar a dudas (por más crítico de la realidad como concepto o por más elogio al perspectivismo), su pertenencia a una clase social que se puede delimitar por su capacidad de influir en los mercados nacionales e internacionales al ser accionista de las trasnacionales y/o propietario de las industrias nacionales (aunque jurídicamente las compañías pertenezcan a las comunidades que viven en un estado determinado) como los déspotas, por ejemplo.

Los dispositivos sociales que se disparan por la centralidad de la industria cultural son complejos ${ }^{2}$. Se globalizan las comunicaciones y proporcionalmente aumentan la multiplicidad de voces e imágenes del mundo, la diversidad cultural se globaliza, brotan miles de espacios de emancipación pero, simultánea- mente, se genera un efecto inversamente proporcional, al globalizarse la lógica de la industria, al massmediatizarse la política, se unifican las formas y maneras de participar en el ámbito público, ergo, se borran, se difuminan, las diferencias, los matices, las miradas, hay una tendencia a unificar la comprensión de lo público. La hegemonía de la imagen y sus lógicas de producción industrial se salen de su ámbito, de su territorio y se apropian no sólo del espacio público sino de las formas de ver y ser de los sujeto.

De lo anterior se desprende la relevancia de repensar no sólo a la industria cultural como totalidad, sino en indagar en acontecimientos que suceden en su interior, como en la televisión (internet, las músicas..), en las telenovelas, por ejemplo, desde las cuales se construyen imaginarios colectivos, narrativas que se configuran en horizontes interpretativos de las relaciones intersubjetivas, etc . La riqueza esta en una comprensión de lo que sucede y una posibilidad, desde los márgenes, de construir narrativas que subviertan relaciones de dominación.

Sin embargo, para una relectura de la industria cultural no basta revisitar sus conceptos y nociones, no basta retematizar los problemas, más bien supone entrenarse en la intemperie, ahondar en el conocimiento ordinario, asumirse un nómada cuyo aprendizaje es la calle, supone entrenar el ojo en los detalles que se configuran en la vida cotidiana. Porque en la calle, en lo ordinario, en lo que sucede a diario, se ancló la comunicación mediática.

\section{Oftalmoplejia Intelectual: Un Problema de la Cultura}

Un síntoma de la cultura universitaria es la enfermedad que se reproduce en los intelectuales: parálisis de la mirada intelectual, oftalmoplejia, mirar en un solo sentido... hacia las bibliotecas. Carecen de entrenamiento para mirar la vida, no como un concepto general de lo que acontece, sino de aquella que se vive. Los que sufren tal enfermedad, pertenecen a los que Barbero y Rey llaman intelectuales con "mal de ojo", porque su insensibilidad hacia la televisión es consecuencia de su falta de empatía con el mundo, porque lo cotidiano no pertenece a su campo visual.

La arqueología de lo que hemos llamado oftalmoplegia intelectual, la podemos encontrar en la investigación que mostró Michel Foucault en sus clases, entre 1981 a 1982, y que fueron recopiladas con el nombre de La hermenéutica del sujeto. También en la indagación realizada por Pierre Hadot titulada: ¿Qué es la filosofía antigua? En ellas se describen cómo y por qué se fracturó la relación entre los discursos de verdad y la vida, cómo y por qué la vida se exilió de las reflexiones intelectuales.

Los pensadores sostendrán que en la época helenística se configuró una cultura de sí. Dicho vocablo lo utilizan porque en tal período se cumple un conjunto de condiciones necesarias que caracterizan el sentido de la palabra cultura, que existan unos valores que estén coordinados y jerarquizados, plantea- 
dos para todos pero accesibles sólo para algunos; siendo el camino para alcanzarlos, unas prácticas reguladas que se habían configurado en el tiempo a través de la trasmisión oral y/o escrita, articuladas como enseñanzas y asociadas a conceptos, ideas y/o teorías. (Cfr. Foucault 2004: 179)

La fractura de la cultura de sí, de la separación entre discurso filosófico y vida, se inicia en la escolástica y llega a su momento culmen con la aparición de la ciencia moderna o lo que llama el autor el momento cartesiano. Así lo dice Foucault:

El corte no se produjo así. No se produjo el día que Descartes postuló la regla de la evidencia o descubrió el cogito, etcétera. Ya hacía mucho tiempo que se había iniciado el trabajo para desconectar el principio de un acceso a la verdad planteado en los términos del mero sujeto cognoscente $\mathrm{y}$, por otro lado, la necesidad espiritual de un trabajo del sujeto sobre sí mismo, para transformarse y esperar la verdad su iluminación y su transfiguración. Hacía mucho tiempo que había empezado a plantearse la disociación y se había colocado cierta cuña entre estos dos elementos. $Y$ la cuña, por supuesto, hay que buscarla... ¿Por el lado de la ciencia? En absoluto. Hay que buscarla por el lado de la teología. La teología al darse como reflexión formal que, a partir del cristianismo, desde luego, funda una fe que tiene en sí misma una vocación universal, fundaba al mismo tiempo el principio de un sujeto cognoscente en general, sujeto cognoscente que encontraba en Dios , a la vez, su modelo, su punto de cumplimiento absoluto... Creo que hay comprender con claridad el gran conflicto que atravesó el cristianismo, desde finales del siglo V (San Agustín, sin duda) hasta el siglo XVII. Durante esos doce siglos, el conflicto no se dio entre la espiritualidad y la ciencia, sino entre la espiritualidad y la teología. (Foucault, 2004: 40)

El surgimiento del cristianismo, como acontecimiento al interior de la cultura del sí mismo, inflexiona, continua, rotura y hegemoniza las dinámicas sociales del mundo occidental. Es un momento que se expande como una onda. Fractura formas y manera de vivir pero, compleja, y simultáneamente cataliza, fusiona prácticas, vivencias, reflexiones, y valores. Son mares picados encontrados. Tsunamis culturales que renovaron el paisaje de occidente.

El objetivo fundamental de los primeros escritos cristianos era conquistar el derecho a vivir legalmente dentro del imperio. De allí que se encuentren cartas, como la del obispo de Sarde, dirigidas al emperador Marco Aurelio donde describe al cristianismo como una filosofía en el sentido dado en su época, como una manera de vivir. Tal propuesta la inscribían los apologistas de la iglesia a partir de una reconceptualización de la historia de la filosofía. Clemente de
Alejandría (150-215 d.c), por ejemplo, sostendrá que en Platón, en Pitágoras y en algunos estóicos, se encuentran verdades encubiertas que hacen de la filosofía una propedéutica para el cristianismo y, por lo tanto, se puede leer el cristianismo a partir de aquellos. Idea que florece, en todo su esplendor, en los escritos de San Agustín.

Lo que pudiera interpretarse en sus inicios como una estrategia política por parte del movimiento cristiano dentro del imperio, presentar su religión como una filosofía que está articulada con el pensamiento griego, se transformó en una práctica sustancial en el seno de la institucionalización de la iglesia; esto es, el uso de los clásicos griegos y romanos para la interpretación de las escrituras. Las filosofías empezaron adquirir el sentido de herramientas para esclarecer el texto supremo más que dilucidar problemas cotidianos.

La amalgama, greco-romana-judío-cristiana, no sólo se dio en el plano teórico sino también en el ejercicio de algunas prácticas. La espiritualidad cristiana tomó de la filosofía antigua algunos ejercicios, técnicas, hábitos...como el examen de conciencia, la atención a sí mismo en diálogo maestro-discípulo...

Pero, quizás una de las prácticas espirituales que reinterpretó el cristianismo y que influyó de forma decisiva en el devenir de la cultura como tendencia a la escisión entre filosofía y vida, fue la que se estableció en los centros de la perfección cristiana, en los monasterios, la meditación. Práctica que, en su devenir, se transformó en la columna vertebral de la cultura universitaria, cuando la meditación se hizo método y el método se hizo lo relevante del pensar.

Epicteto ilustra de qué trataba el ejercicio, decía: Estos son los pensamientos que deben meditar los filósofos, esos los que deben escribir todos los días, los que deben ser su materia de ejercicio (Epicteto, Entrenamientos, I, 1, 25) Se trataba de pocos pensamientos que el ejercitante debía repetir, debía meditar, esto es apropiárselos, hacerlos para sí y esto se lograba con la lectura y escritura de los mismos.

No se trata - sostiene Foucault (2004: 341) - de comprender lo que quiere decir un autor sino la constitución para sí de un equipamiento de proposiciones verdaderas, que sea efectivamente nuestro... No es cuestión de armarse de una marquetería de proposiciones de orígenes diferentes, sino de constituir una trama sólida de proposiciones que valgan como prescripciones, de discursos de verdad que sean al mismo tiempo principios de comportamiento... La lectura se prolonga, se fortalece, se reactiva por la escritura, escritura que es también un ejercicio, también un elemento de la meditación.

Tal práctica se configuró en el eje central de la vida en los monasterios a partir del siglo VI, cuando San Benito la establece en sus reglas. Ahora bien, tal como 
en la antigüedad, no se trataba de leer cualquier cosa ni de cualquier procedencia, sino aquello conducente a una vida buena. De allí que el libro fundamental fuese las sagradas escrituras. Sin embargo, San Agustín había aceptado que el cristiano podía prepararse, para la vida, con la lectura de los filósofos griegos como Platón y Aristóteles, tal como era cultura en la época donde la lectura filosófica correspondía a etapas de vivencias espirituales ${ }^{3}$. Por lo tanto, el criterio de selección de los textos implicaba ya una orientación de la manera de vivir. La lectura, sus comentarios, su escritura, sus resúmenes, la reiteración de las ideas principales en la soledad, configuraba una de las prácticas espirituales por excelencia dentro del claustro.

Aún más el ejercicio de leer y escribir, en principio con la sola reiteración, pero luego con los comentarios se engranaron en un solo texto. El nuevo libro estaba constituido tanto por la lectura como por sus glosas. Éstas, las glosas, eran de dos órdenes, interlineales o marginales. Las que estaban al margen eran la expresión de la interioridad del lector, su interpretación. De allí que éstas se configuraron como exposiciones que tenía por sentido explicar las lecturas tanto literales como glosadas de forma interlineal.

Justamente, la relevancia que fue adquiriendo en el tiempo las exposiciones condujo a los monjes medievales a establecer un momento sólo para la discusión de las cuestiones que surgían en las exposiciones. Momento distinto de la práctica de la lectura y escritura. Momento distinto de las horas de meditación. Tales cuestiones se transformaron en las disputas teóricas donde se presentaban, caracterizaban y proponían soluciones interpretativas.

La filosofía se transformó, entonces, en un medio de interpretación de los libros sagrados. Dejó de ser un abanico de opciones existenciales al hegemonizarse, como única alternativa de la existencia, la vida cristiana. El clima es el del imperio vaticano que se levantaba como espectro del imperio romano en el mundo viejo europeo. En ese ambiente el filósofo se transformó no en un hombre que elige una manera de vivir y da cuenta de ella porque vale la pena vivirla sino en aquél que comenta, explica e interpreta los textos antiguos. La vida es la que debe ser y la que debe ser está expuesta en la doctrina. La doctrina es fruto de la interpretación de los libros sagrados. Por lo tanto, el método para dar cuenta de la verdad del texto se transformó en la obsesión fundamental.

Con ese mismo espíritu Descartes medita sobre el método ya no para encontrar la verdad del texto. Su pretensión está más allá, su vocación es para dar cuenta de las verdades claras y evidentes en términos generales. Con Descartes la meditación se hizo método y el método se hizo el objeto del pensar. Para Kant el camino se vislumbraba seguro, era el método de la ciencia. Newton y su análisis se transformaron en el paradigma metódico de todo saber. Para Comte la ciencia era la nueva religión. La razón científica fue la nueva diosa. Ella comprendía la totalidad porque era capaz de separar y reconstruir con una secuencia ordenada, siguiendo una regla, una ley. Durkheim sostenía que había encontrado la ley universal de gravedad de la cohesión social, el cómo y el por qué vivir juntos...

La filosofía se asumió como el saber que piensa a la ciencia. Se preocupó por las condiciones, posibilidades y límites del conocimiento, por los criterios de validez de las argumentaciones, por los ámbitos de legitimidad de las decisiones, se dedicó al pensamiento de las estructuras y sobre todo quedó con la obsesión de indagar en la opacidad de los conceptos, rastreando palabras por la palabra misma, su arte fue componer diccionarios a manera de tratados. Su historia se configuró como una historia de sistemas de pensamientos. Se olvidó la vida.

Casi como una cosa tonta y sin sentido quedó la interpelación por la vida que vale la pena vivir. Las reflexiones sobre la amistad quedaron en el olvido. La contingencia y la elección de sí quedaron como anécdotas. Lo que se llamó filosofía práctica era la interpretación de la filosofía aristotélica donde Aristóteles pensaba su mundo. Filosofía práctica se trataba de los ejercicios exegéticos sobre la Ética a Nicómaco o sobre la Política. La filosofía práctica estaba vacía de la vida del pensante.

Tal espíritu hermenéutico (ejercitar la mirada y los sentidos, para ver, olfatear, interpretar y resolver problemas de interpretación en los libros antiguos) nacido en el seno de la tradición monástica configuró el alma de las universidades medievales y, por supuesto, en el arquetipo del quehacer de tal institución en su devenir. Bien lo dice Pierre Hadot (1998:280):

Esta representación de una filosofía reducida a su contenido conceptual sobrevivió hasta nuestros días: la encontramos a diario, tanto en los cursos de la universidad como en los manuales escolares de todo nivel. Se podría decir que es la representación clásica, escolar, universitaria, de la filosofía. Inconsciente o conscientemente, nuestras universidades siguen siendo herederas de la Escuela, es decir, de la tradición escolástica.

Tal práctica hermenéutica unida al ideal de vida platónico y agustiniano de apartarse del mundo para contemplar a Dios, mezclado con el clima que se configura a partir del siglo XVIII donde Dios se sustituyó por la Razón y la abstracción por el deber ser... amoldó la mirada del intelectual. Se le hizo rígida, vio en un solo sentido, sólo miraba la armonía conceptual, se hizo contemplativo. Hoy día el intelectual no tiene práctica para poder ver en la intemperie, tiene una enfermedad cultural que se encubó desde el siglo $\mathrm{V}$.

Salir a la intemperie, salir del claustro, del monasterio hermenéutico y lanzarse en el clima de estos tiempos a la calle, con la empática de transformarnos y pujar por transformar contextualmente las situaciones de dominio, es la propuesta. La obra, la escritura, el pensamiento y sus horizontes, quizás se pueden 
delinear con aquella sentencia que le escribió Horkheimer a Lowenthal en 1942, "Mientras más grande es una obra, más enraizada está en la situación histórica concreta."

Se trató de quince siglos de aprendizajes de biblioteca en olvido de la vida cotidiana; se trata ahora de embadurnarse del mundo. Se trata de una hermenéutica de la facticidad, para optar existencialmente, por una praxis conforme con lo que se es.

Dejemos de adorar las opiniones y nutrámonos del estoicismo antiguo como fuente de sabiduría para el tiempo presente. Quizás así pasemos de la aceptación de los hechos a un amor profundo de los hechos. Del amor fati al amor mundi. El mundo sólo es miserable para quienes en él proyectan su propia miseria. Con demasiada frecuencia el malestar de la intelligentsia es, en efecto, la medida para la apreciación de las cosas... Demasiados obnubilados por una lógica del deber ser, cuyos contornos son de lo más rígidos, hemos olvidado por completo ese poderoso relativismo popular, profundamente arraigado, para el cual "el mundo en que penetramos al nacer es brutal y cruel y, al mismo tiempo, de una belleza divina." Ahí se encuentra precisamente el drama esencial de este fin de siglo que presencia la apertura de un abismo entre quienes viven y quienes dictan sobre el mundo, o piensan actuar sobre él. (Michel Maffesoli, 2004:9-10)

\section{Ni Anais Nin Ni Simon de Beauvoir: es Marilyn.}

El titulo del parágrafo es una metáfora que intenta dar cuenta de un cambio de registro, de una discursividad que se desplaza del estrecho y poderoso ambiente intelectual al campo del espectáculo, para todo público. La fuerza de la telenovela como espectáculo es su poder de penetración en las configuraciones de la subjetividad del televidente, de su posibilidad de poner en cuestión los valores, la moral, la religión y hasta las buenas costumbres con el aplauso incorporado. El título es una metáfora que alude a la fuerza del espectáculo frente a la muerte de los tratados filosóficos, por más desgarradores que hayan sido. Como muestra de tal acontecer, a manera de pincelada quisiera recrear brevemente la telenovela: "Todos quieren con Marilyn", telenovela colombiana del 2004, escrita por Juan Carlos Pérez y dirigida por Pepe Sánchez.

Se trata de una historia de amor entre Marilyn, una prostituta quien utiliza el nombre de Marilyn Monroe porque representa ese papel en los show que realiza en el centro nocturno donde labora y Juan Ignacio, un abogado exitoso que labora en el bufete donde su padre es socio de su suegro.

Es una historia aunque tramada con la lógica de la similitud de la industria cultural, se diferencia en la forma de contarla, en los diálogos y en la vida que desean los personajes secundarios.

El hilo conductor de la narración es la relación de
Marilyn con Juan Ignacio. A partir de ella se muestra la vida de las mujeres que trabajan en "Las Divas", un prostíbulo ubicado en una zona residencial de clase media que funciona ilegalmente. Su dueño, tras bastidores, es un político. Un diputado respetable, quien impulsa, paradójicamente, la ley contra el delito de trata de blanca y la regulación de locales nocturnos, cuyo socio es uno de los diseñadores más respetables de Colombia, quien participa en una red internacional de trata de blanca. Éste es apresado, al final de la telenovela, cuando declaraba, a propósito de un desfile de modas que realizaría en New York, que él representaba a Colombia. Quizás la imagen del diseñador cuando es arrestado resume lo central de ficción televisiva: La denuncia de la doble moral.

Pero la denuncia y el cuestionamiento no sólo se dan en el orden social, sino también en la esfera priva$\mathrm{da}$, con respecto a la moral, a la educación, a la configuración de la familia... La historia de la familia Pachón, es la historia del deber ser, del puritanismo religioso como horizonte comprensivo de la vida y de la infelicidad que produce tal mirada en el quehacer, en la vida de todos los días. Lorenza Pachón, la mujer con la que Juan Ignacio se casa cuando se inicia la trama, es una mujer castrada sexualmente, por los prejuicios religiosos, y vive con la ficción que el deber ser es lo que es, por lo tanto, el matrimonio cueste lo que cueste debe ser para toda la vida aún siendo infelices. Esa es la herencia educativa de sus padres.

Sin embargo, en el desarrollo de la historia, ella se descubre distinta al confrontarse con Marilyn. Ambas mujeres no sólo disputaban el amor de Juan Ignacio, sino que confrontaron visiones del mundo, en tal interacción Lorenza que ella es lo que no desea ser y lo que desea ser no es lo que dicta su deber ser.

La guerra de miradas posibilitan que Lorenza descubra que la vida que desea vivir no es la de casada, se descubre a sí misma, en la contingencia, como una mujer que quiere romper con su pasado, subvertir su formación se transforma en su mayor deseo y su liberación no es otro que el disfrute del cuerpo, sin proyecto de familia, sin pensar en el futuro, sólo el instante la constituye.

Los Padres de Lorenza, son una pareja que han vivido toda una vida de casados sin comunicarse el disgusto que sufren por no disfrutar del sexo, una por verlo como pecado y el otro por sentir displacer por la frigidez de su mujer. La realización de ambos como pareja la consiguen al final de la trama, al descubrir sus cuerpos. Esto se da por la contingencia del encuentro con el mundo de la prostitución. La terapeuta que ayuda a la pareja es Marilyn, quien es su antítesis, la inmoral, la prostituta, la pecadora. Sin embargo, es en el diálogo con ella, en el vivenciar situaciones y en la confrontación de los valores donde la pareja Pachón descubren el disfrute y el goce del encuentro de dos cuerpos, la santidad del sexo.

La crítica a la utilización del sexo por parte del poder, también las revela al interior de la industria 
cultural, cuando Ingrid, una prostituta cuyo deseo es ser actriz, decide acostarse con todo aquel que tenga poder de decisión en la empresa de comunicación con tal de actuar en una telenovela. Con todos se acuesta y ninguno la contrata.

Tal historia permite narrar no sólo la relación de dominación de los hombres a las mujeres, a través del sexo, sino también abre una brecha para la narración de la ficción dentro de la ficción, cuando Ingrid es contratada para protagonizar una novela sobre la vida de unas prostitutas.

Es relevante mostrar que tal episodio le permite al narrador hacer una crítica, sutil, a la estructura de decisión en la producción de telenovelas, ni el escritor, ni el director deciden sobre quiénes son las actrices, sino una ejecutiva del canal, siendo ella quien elige a Ingrid. Cuando Marilyn ve la telenovela de su amiga, donde presentan la relación de una prostituta enamorada de un cliente millonario, comenta: En las telenovelas todo es más fácil. En definitiva, la telenovela Todos quieren con Marilyn puede leerse como un síntoma, como un acontecimiento cuya discursividad cuestiona de forma simultánea a la educación ortodoxa cristiana, la doble moral del poder económico y político, la explotación sexual dentro de la industria cultural, las telenovelas como productos, la apariencia como telos de la sociedad burguesa (representado por Catalina, una joven universitaria que desea tener el estatus de sus amigas y por tal ambición, sufre las consecuencias de ser vendida a una mafia japonesa) y, sobre todo, el descubrimiento del disfrute del cuerpo, el sexo como manifestación de encuentro y goce, como manifestación de la vida que vale la pena vivir.

Justamente, adentrarse en el conjunto de significados y símbolos que se desprenden de la telenovela, adentrarse en los imaginarios que presenta y aquellos valores que cuestiona, es sumirnos en las problemáticas del devenir de la cultura en América Latina.

Justamente, mirar en tales resquicios es el inicio de una reapropiación crítica de la industria cultural en estos tiempos, porque tienen "(...) la propiedad de revelar la cartografía de los sentimientos tanto como las tensiones de lo social, las propiedades de la imaginación cultural como las aspiraciones secretas y explícitas de la gente que la sigue con fervor." (Barbero y Rey, 1999: 144) चfamecos

\section{NOTAS}

1. El problema ya no es unos demonios que son propietarios de unos medios de comunicación que tiene intereses políticos... Eso sería relativamente fácil de resolver. La cosa es más sutil. Se trata de las miradas. La mirada del propietario de medios, se instaló en la mirada del sujeto político que pueden o no coincidir en las tramas de las divisiones sociales, incluso, pueden ser antagónicos en la lucha social, pero sus formas de mirar huelen a show, a publicidad y mercadeo, para bien o para mal, esto es un dato de nuestra época.
2. A penas hemos realizado un mínimo boceto, muy somero, en un ámbito de la vida social, de la cultura massmediática en la que vivimos... hay una buena y abundante bibliografía que se adentra en el ámbito educativo, en la configuración de las empresas, en las relaciones amorosas, etc...

3. Por ejemplo, los neófitos se iniciaban en el arte del pensar filosófico a través del Alcibíades, dice Proclo (412-485) al respecto: Este diálogo es el principio de toda la filosofía, como lo es en la misma medida el conocimiento de nosotros mismos. Por eso en él se diseminan y trasmiten como tradición varias consideraciones lógicas, encuentran su esclarecimiento varias consideraciones morales que contribuyen a nuestra investigación sobre la eudemonía y se exponen de manera sumaria varias doctrinas aptas para llevarnos al estudio de la naturaleza e incluso a la verdad en lo tocante a los seres divinos, a fin de que en este diálogo se contenga como modelo un único bosquejo general y total de toda la filosofía, bosquejo que se nos revela gracias, precisamente a ese primer retorno a nosotros mismos. (Proclo citado por Foucault, 2004:171)

\section{REFERÊNCIAS}

ADORNO, Horkheimer. Dialéctica del iluminismo. Buenos Aires: Sur, 1971.

ADORNO, Theodor. Crítica cultural y sociedad. Barcelona: Ariel, 1973.

JONATAN, Alzuru. El problema de la alpargata en la modernidad, En: Diversidades. Caracas: Ceprosod, 1991.

REY G., Barbero M. Los ejercicios del ver. Barcelona: Gedisa, 1999.

BARRIO, arrio, Leoncio. La Escuela de Francfort y la crisis cultural de nuestro tiempo, En: Industria Cultural. Caracas: Litterae Editores, 1999.

FOUCAULT, Michel. La hermenéutica del sujeto. México: F.C.E, 2004.

HADOT, Pierre. ¿Qué es la filosofía antigua?. México: F.C.E, 1998.

MARCUSE, Herbert. Razón y revolución. Madrid: Alianza, 1971.

MAFFESOLI, Michel. El nomadismo. Vagabundeos iniciáticos. México: F.C.E., 2004.

\section{VATTIMO, Gianni. Posmodernidad: ¿Una sociedad} transparente? En: En torno a la posmodernidad. Bogotá: Anthropos, 1994. 